\title{
Effect of Cadmium on the Embryonic Development and Hatching Rhythm of Big Fin Squid Sepioteuthis lessoniana, Lesson (1830) from Palk Strait, East Coast of India
}

\author{
Vasanthi LA ${ }^{1 *}$, Revathi $\mathbf{P}^{1}$, Munuswamy $\mathbf{N}^{2}$ and Ramaswamy Babu $\mathbf{R}^{1}$
}

${ }^{1}$ Department of Environmental Biotechnology, Bharathidasan University, Trichy-620024, Tamilnadu, India

${ }^{2}$ Department of Zoology, University of Madras, Guindy campus, Chennai-620025, Tamilnadu, India

\begin{abstract}
In the present study, the impact of cadmium on embryonic development, morphology of eggs and newly hatched larvae of the Sepioteuthis lessoniana were described using the laboratory-reared specimens originating from Thondi, South East coast of India. The eggs were exposed to a concentration of $25 \mu \mathrm{g} \mathrm{Cd} / \mathrm{L}$ for up to hatching. The average incubation period of the eggs varied between $18-23$ days and the estimated mean temperatures were $18.6 \pm 0.7^{\circ} \mathrm{C}$ for control, and $19.2 \pm 1.1^{\circ} \mathrm{C}$ for $\mathrm{Cd}$ exposed groups. The results revealed that a total hatching rate of $99.2 \pm 1.6 \%$ was achieved in control group and only $65.2 \pm 8.8 \%$ in treated group. The deformities of the paralarvae were illustrated with light and scanning electron microscopy. In conclusion, the present concentration exhibited toxic effects to the eggs and paralarvae of $\mathrm{S}$. lessoniana. Therefore, $\mathrm{Cd}$ level as high as we used in this study could give good information on dangerous $\mathrm{Cd}$ levels on squid.
\end{abstract}

Keywords: Squid; Cadmium; Paralarvae; Larval bioassay; Embryos; Heavy metals

\section{Introduction}

Heavy metals enter aquatic ecosystems from various sources such as municipal wastewater, liquid industrial waste discharges, and river runoff. They can cause adverse effects on aquatic organisms if adequate concentration of chemicals comes into contact with a biological membrane of an organism or system [1]. At higher levels of biological organization (tissue, organ and whole organism), heavy metals induce changes in metabolism, biochemistry, physiology, and histology, and inhibit synthesis of proteins and nucleic acids [2-4]. Most of the studies have highlighted the very high ability of cephalopods to concentrate various toxic elements such as $\mathrm{Ag}$ or $\mathrm{Cd}$ [5-8].

Cadmium (Cd) is among the most toxic metals in the aquatic environment, possesses no known biological role and exhibits high toxicity if allowed to accumulate in metabolically-active tissues [9]. Cadmium is a biologically non-essential heavy metal that occurs naturally and is released from various sources [10]. The cadmium contamination in surface and groundwater is believed to be of non-point source as a result of agricultural and urban run-off. Concentrations of $\mathrm{Cd}$ measured in environmental water samples vary considerably from $1 \mathrm{ppb}$ to over $400 \mathrm{ppb}$ in contaminated sites [11]. Most of Cd forms complexes with ions such as $\mathrm{Cl}$ [12], and only a small fraction of cadmium in the form of free hydrated metal ion form, $\mathrm{Cd}^{+2}$, is biologically available to the organisms [13]. Its average concentration in unpolluted waters is about $0.05 \mu \mathrm{g} \mathrm{Cd} / \mathrm{L} \mathrm{Cd}$. Concentrations of $\mathrm{Cd}$ in coastal waters tend to increase because of anthropogenic input and local geological conditions [14].

Squid accumulate trace amount of heavy metals including Cd, in its liver, digestive gland, mantle, ovary, and eggs from water and food [15]. Cd is transferred from water and food to the squid and from squid to their predators through the food chain. Therefore, squid play an important role in the chain $[6,8,15-19]$. By another hand, no information exist on the incorporation of elements by eggs in cephalopod species that lack eggshell, as in the incirrate octopods (Octopus vulgaris) which egg chorion is in direct contact with seawater. The egg capsules of Sepioteuthis lessoniana are laid on the underside of rocky overhangs, on branched sessile organisms or on fishing lines and hang down in the water [20-24]. Hence, the egg capsules stand wherever laid and expose to every kind of heavy metals from not only the water but also the sediment environments. Moreover, as reported by Bustamante et al. [8], heavy metal levels in cephalopods, which are extensively fished and consumed by human, are also of direct significance to the public health. However, there is only one study related to the effects of the some heavy metals on Loligo vulgaris embryos [24], but seemingly no available study exists in literature on the effects of any heavy metal on development and hatching of eggs of Sepioteuthis lessoniana. Knowledge of the early life history of $S$. lessoniana would provide basic information for fishery biology. It would also be invaluable in the analysis of the phylogeny of the Cephalopoda by clarifying the embryogenesis of squid species that has seldom been previously pursued by researchers. Therefore, the aim of the current study is to determine the effect of $\mathrm{Cd}$ on development and hatching of S. lessoniana eggs collected from the Palk Strait region, South East coast of India.

\section{Materials and Methods}

\section{Egg collection}

Recently spawned egg masses of S. lessoniana, probably by different breeders, had been collected from fishing lines deployed in the Palk Strait region, Southeast coast of India. This region is comparatively less polluted or unpolluted as the site was not surrounded by any industries/urban pollution sources. The egg capsules were transported

${ }^{*}$ Corresponding author: Vasanthi LA, Department of Environmental Biotechnology, Bharathidasan University, Trichy-620024, Tel: +914312407088. Fax: +914312407045; E-mail: arockiavasanthi@gmail.com

Received December 18, 2015; Accepted May 07, 2016; Published May 17, 2016

Citation: Vasanthi LA, Revathi P, Munuswamy N, Babu RR (2016) Effect of Cadmium on the Embryonic Development and Hatching Rhythm of Big Fin Squid Sepioteuthis lessoniana, Lesson (1830) from Palk Strait, East Coast of India. J Biodivers Endanger Species 4: 159. doi:10.4172/2332-2543.1000159

Copyright: () 2016 Vasanthi LA, et al. This is an open-access article distributed under the terms of the Creative Commons Attribution License, which permits unrestricted use, distribution, and reproduction in any medium, provided the original author and source are credited. 
Citation: Vasanthi LA, Revathi P, Munuswamy N, Babu RR (2016) Effect of Cadmium on the Embryonic Development and Hatching Rhythm of Big Fin Squid Sepioteuthis lessoniana, Lesson (1830) from Palk Strait, East Coast of India. J Biodivers Endanger Species 4: 159. doi:10.4172/23322543.1000159

Page 2 of 6

to the laboratory on the same day. Eggs were separated into smaller clusters of four or five egg capsules and placed in the glass aquarium containing filtered sea water and covered with black cloth to avoid the growth of algae. The egg masses were sorted according to embryonic development stages based on Naef's [25] (Roman numerals) and Arnold's [26] (Arabic numerals) criteria, and then their morphometric characteristics were measured $(\mathrm{n}=30)$. During the experimental period, embryonic development stages of the eggs were observed under a stereo microscope (20-40X magnification). The embryonic development stage was 13 (II) at the commencement of the trials, which is the gastrula stage.

\section{Stock solution}

Cadmium chloride $\left(\mathrm{CdCl}_{2}\right)$ (95\% purity) was purchased from Himedia (Himedia, India). Two hundred and fifty milligrams of $\mathrm{CdCl}_{2}$ was dissolved in $100 \mathrm{ml}$ of double distilled water.

\section{Experimental design}

All trials were performed on two bunches of egg capsules including average $110 \pm 9.8$ eggs in triplicate ( $n=6$ egg capsules per concentration) without any acclimation process. The egg capsules were grouped into two, one group served as control and other group exposed to a concentration of $25 \mu \mathrm{g} \mathrm{Cd} / \mathrm{L}$. The experiments were conducted with continuous aeration, optimum temperature and salinity. Sea water containing experimental $\mathrm{Cd}$ concentrations was changed every day by replacing $100 \%$ of the beaker volume. Illumination (a $40 \mathrm{~W}$ fluorescents tube) was controlled by a timer to provide a photoperiod of 12:12 h of light: dark periods. All embryos in the egg capsules were examined every day in the control and exposed groups until hatching. The main criterion of death of egg was whitening of the yolk of embryo. The length of the incubation period (D), total hatching $(\mathrm{TH}=[$ number of hatching eggs (premature and swimming paralarva at nearly the water surface)/ number of incubated eggs]*100), and hatching success (HS $=$ [number of healthy and swimming paralarvae at nearly water surface/number of incubated eggs] ${ }^{*} 100$ ) of the eggs were estimated for both control and each experimental group (Sen 2005a, b). The length of egg capsules were measured with measurement board to the nearest $\mathrm{mm}$, egg dimensions (length and width) were measured by millimetric ocular to the nearest $0.01 \mathrm{~mm}$, and numbers of eggs per capsule were counted by macrometric observations. During hatching, newly hatchlings (paralarvae) were harvested from the beakers and counted daily.

\section{Histology}

For histological studies, paralarvae were taken from both control and experimental groups and fixed in Bouin's fixative. The samples were dehydrated through graded alcohol series and embedded in paraffin wax. Sections of 6-8 $\mathrm{mm}$ thickness were taken, dehydrated and stained with hematoxylin and eosin. The stained sections were mounted using DPX and photomicrographs were taken using Leica 2500 microscope (Germany).

\section{Scanning electron microscopy (SEM)}

Paralarvae of both control and Cd treated were fixed in 2.5\% glutaraldehyde in seawater for $15 \mathrm{~h}$, washed in seawater followed by dehydration in an increasing concentration of ethanol (20,30 and $50 \%$ ) and stored in ethanol $70 \%$ at $4^{\circ} \mathrm{C}$. At the beginning of the SEM preparation, the samples were again dehydrated in an increasing concentration of ethanol $(80,90$, and $95 \%)$ until they were saturated in absolute ethanol. Each ethanol bath lasted $10 \mathrm{~min}$. After complete dehydration in the ethanol series, the samples were dried to the critical point, which was carried out in a Bal-Tec CPD 030 Drier using $\mathrm{CO}_{2}$ as the transition liquid. After the drying stage, samples were mounted on stubs with double-sided conductive sticky tape to orientate them in the preferred position. The mounted samples were sputter coated with gold-palladium in a Polaron Sputter Coater SC500. Finally, the samples were observed using a scanning electron microscope (Hitachi S3500N).

\section{Statistics}

The obtained data were given as mean \pm SD values in the text, and were compared using one-way analysis of variance (ANOVA) to determine significant differences among means $(\mathrm{p}<0.05)$. Statistical analyses were carried out by SPSS 11.0 software.

\section{Results}

During the experimental period, the ambient temperature ranged between 16.3 and $20.5 \mathrm{C}$, and the estimated mean temperatures were $18.6 \pm 0.7^{\circ} \mathrm{C}$ for the control, and $19.2 \pm 1.1^{\circ} \mathrm{C}$ for $\mathrm{Cd}$ exposed groups. There were no significant differences in water temperatures between control and Cd exposed groups ( $\mathrm{p}>0.05$ ).

\section{Egg morphology}

Morphometric characteristics of the egg capsules and eggs were given in Table 1 (Figure 1A). The total incubation period of the big fin squid S. lessoniana varied between 18-23 days. As the development of the embryos progressed within, the egg capsule became more transparent and slightly enlarged with the absorption of water. Embryos were present in most of the capsules seen through as a white mass and occasionally moving within the capsules of both control and Cd treated groups. From thirteenth to seventeenth day, the yolk totally reduced and the organs of the embryo started to develop. Decreasing of yolk is another important character to confirm the development of embryo. Before hatching they floated in the capsule for some time and wriggled out through a small slit in the capsule (Figure 1B). By the time the embryo became a full-grown young within the capsule, the yolk would have been fully absorbed. But in Cd exposed group the diminished yolk

\begin{tabular}{|c|c|c|c|c|}
\hline Value & $\begin{array}{c}\text { Capsule } \\
\text { Length }(\mathbf{m m})\end{array}$ & $\begin{array}{c}\text { Eggs per Capsule } \\
\text { (nos) }\end{array}$ & $\begin{array}{c}\text { Egg length } \\
\text { (mm) }\end{array}$ & $\begin{array}{c}\text { Egg width } \\
\text { (mm) }\end{array}$ \\
\hline Min & 50 & 4 & 20 & 10 \\
\hline Max & 80 & 7 & 25 & 18 \\
\hline Mean & 69 & 5 & 23 & 14 \\
\hline SD & 8 & 0.002 & 2 & 3 \\
\hline
\end{tabular}

Table 1: Morphometric characteristics of the egg capsules and eggs.

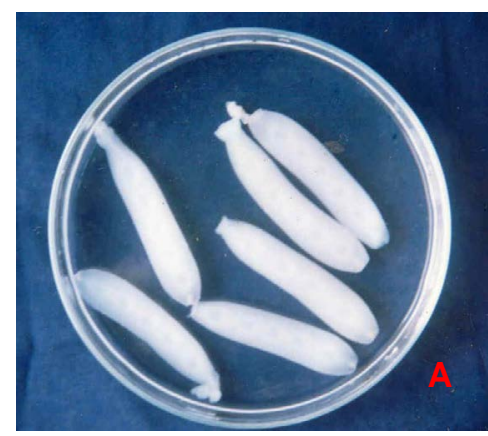

Figure 1A: Photograph of egg capsules of Sepioteuthis lessoniana separated from the egg strand. 
Citation: Vasanthi LA, Revathi P, Munuswamy N, Babu RR (2016) Effect of Cadmium on the Embryonic Development and Hatching Rhythm of Big Fin Squid Sepioteuthis lessoniana, Lesson (1830) from Palk Strait, East Coast of India. J Biodivers Endanger Species 4: 159. doi:10.4172/23322543.1000159

Page 3 of 6

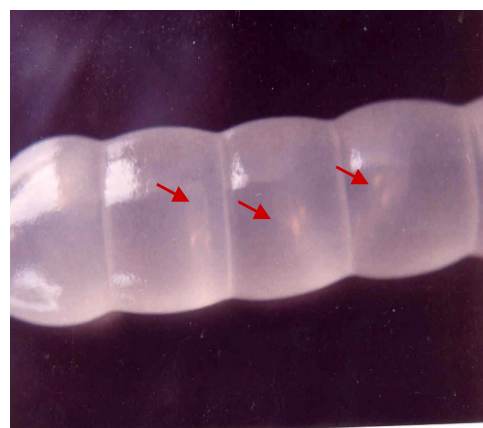

Figure 1B: 12 Days old embryo inside the chorionic capsule.

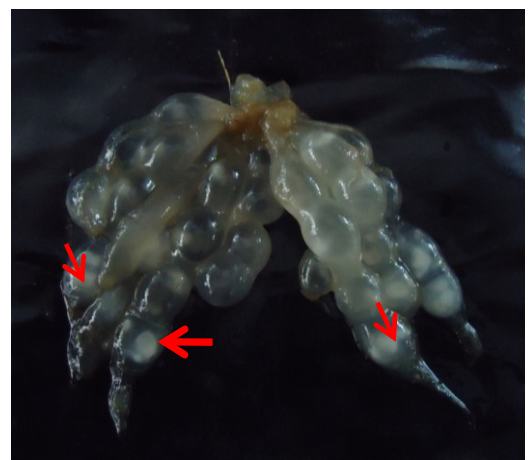

Figure 1C: Cadmium exposed eggs showing yolk sac within the capsules

sac still persisted and yolk sac could be seen within the empty capsule (Figure 1C). The embryo with its mantle, head and arms resting on the globular yolk sac was more visible through the capsule. Hatching took place between the hours 432 and 456 in control group and between the hours 456 and 480 in Cd exposed groups. Total hatching rate was $99.2 \pm$ $1.6 \%$ in control group, while the estimated hatching success rates were $65.2 \pm 8.8 \%$ in the treated group. Significant differences were found in total hatching and hatching success rates among the groups $(\mathrm{p}<0.05)$.

\section{Morphology of the paralarvae}

Control: In control, the paralarvae showed a normal morphological aspect and swam actively in the glass tank. Before hatching they floated in the capsule for some time and wriggled out through a small slit in the capsule. By the time the embryo became a full-grown young within the capsule, the yolk would have been fully absorbed. The hatched young ones of $S$. lessoniana were the miniature replicas of the adult cuttlefish externally. At this stage they measured $6.5-7 \mathrm{~mm}$ in dorsal mantle length. The chromotophores were very clear and distributed all over the body with prominent brown dots (Table 2). By the end of the experiment, chromotophores on the body were clear and heart beating was evident in some of the embryos. Nevertheless, mean survival was relatively high in the control group, no malformations were observed and paralarvae were capable to swim actively (Figures 2A and 2B).

Experimental group: In Cd treated group, most of the embryos remained in early developmental stages, the only observable evidence of organ formation being the rudiments of the pigmented eyes, stunted growth of arms and mantle. Therefore, the paralarvae showed large amounts of vitelline reserves in their external yolk sac (Figure $3 \mathrm{~A})$. Seven days $(168 \mathrm{~h})$ after fertilization, premature hatching was observed (Figure 3B). In some cases, few embryos reached late stages of development but showed malformations such as eyes further apart from each other and the internal yolk sacs broader than in morphologically normal embryos and no one succeeded to hatch (Figure 3C). Also, they were poorly active when stimulated by light during the incubation. Chromatophore formation has not seen in the body. Embryos were unable to break their chorionic membranes, remaining at this stage for few days, until they completely consumed their vitelline reserves and died. Almost all premature hatchlings died within the capsule. Statistical analyses suggest that survival was significantly different between treatment and control groups.

\section{Histological changes associated with cadmium toxicity}

Section through the paralarvae of control showed large rounded prominence on each side of the bed marks, the position of the eyestalk. The eye stalks are now very conspicuous projections from the sides of the dorsal end of the embryo. Eye primordia were clearly visible in the paralarvae and comprised of a shallow hemispherical

\begin{tabular}{|c|c|c|}
\hline Days & No of Hatching & Rate of Mortality \\
\hline 16 & $2 \pm 0$ & - \\
\hline 17 & $8 \pm 1$ & $5 \pm 1$ \\
\hline 18 & $57 \pm 3$ & $10 \pm 3$ \\
\hline 19 & $140 \pm 5$ & $59 \pm 7$ \\
\hline 20 & $33 \pm 2$ & $166 \pm 10$ \\
\hline
\end{tabular}

Table 2: Hatching and mortality rate of the paralarvae of big fin squid Sepioteuthis lessoniana.
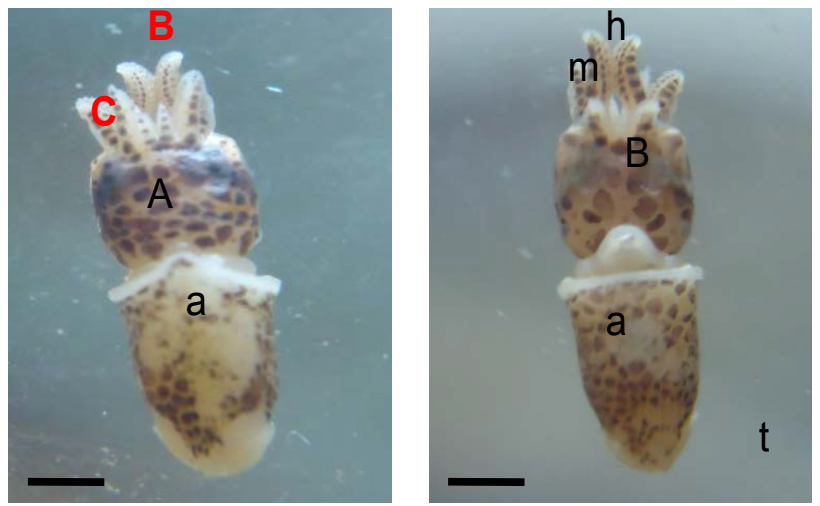

Figure 2: $(2 \mathrm{~A})$ Dorsal and $(2 \mathrm{~B})$ ventral view of the paralarvae of Sepioteuthis lessoniana showing the shape and disposition of the chromatophores in the arms (a), tentacles $(\mathrm{t})$, head $(\mathrm{h})$, mantle $(\mathrm{m})$ and body $(\mathrm{b})$. Scale bar: $11 \mathrm{~mm}$.
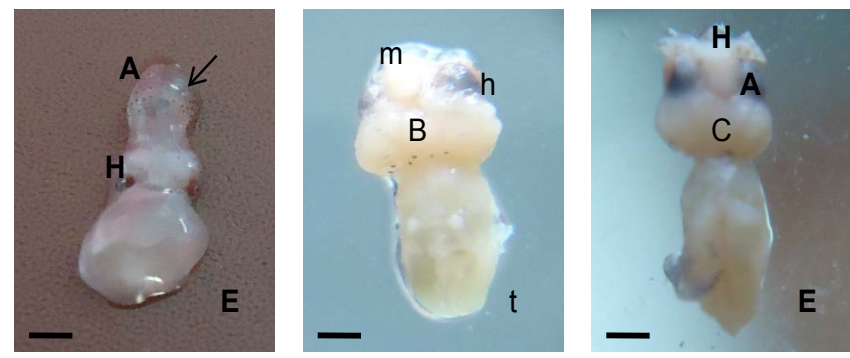

Figure 3A-C: Premature hatchlings in cadmium treated group (3A). Early developed embryo with vitellin reserves (VR) on the dorsal side, rudimented eye (E) Sacale bar: $8 \mathrm{~mm}$. (3B). Stunted arm development (A), rudimented eye $(E)$, distorted head $(H)$ Scale bar: $9 \mathrm{~mm}(3 C) 17^{\text {th }}$ day pralarvae with malformations in the eye $(E)$, arms $(A)$ and head $(H)$ Scale bar: $11 \mathrm{~mm}$. 
Citation: Vasanthi LA, Revathi P, Munuswamy N, Babu RR (2016) Effect of Cadmium on the Embryonic Development and Hatching Rhythm of Big Fin Squid Sepioteuthis lessoniana, Lesson (1830) from Palk Strait, East Coast of India. J Biodivers Endanger Species 4: 159. doi:10.4172/23322543.1000159

cup of undifferentiated neural retina which, along with presumptive lentigenic and iris cell tissues, enclosed a posterior eye chamber (Figure $4 \mathrm{~A})$. The ridges of the head divided into three arms, upon each side of the body, about half-way between the mantle and the opposite pole of the egg (Figure 4B). However, in cadmium treated paralarvae, the rudiments of the eye-stalk could be seen on one end of the dorsal view (Figure 4C). Eye primordial was not clear as in control. The pair of arms makes their appearance as buds upon the next pair and appeared as elevations of the integument upon the surface of the body (Figure 4D).

\section{Ultrastructural changes associated with cadmium toxicity}

Under scanning electron microscopy, control showed well developed eye-invaginations. The eye-stalks are much more prominent, and the head, mantle and body are divided into three well-marked regions. The funnel folds arise as bulge of tissue which form a V-shaped structure medial to the eyes, posterior to the arms, and anterior to the down-growing mantle (Figure 5A). The three pairs of arms, are much elongated, and begin to bend away from the surface and the suckers have appeared upon the longest pair (Figure 5B). The mantle is smooth and connects well with the body (Figure 5C). In contrast, the head arms and mantle of Cd treated paralarvae are very much smaller as compared with the control. The formation of funnel fold is poorly developed on the mantle (Figure 5D). The eye invaginations are not visible. Arm ridges are stunted and irregularly arranged (Figure 5E). The surface topography of the mantle showed rough, narrow downwards and weakly joined to the body (Figure 5F).

\section{Discussion}

Squid egg strand is characterized by a complex structure in which several small oocytes surrounded by a chorion are united by oviducal jelly, and enveloped by a common sheet of nidamental secretions [27]. Cuttlefish hatchlings are essentially isometric copies of adults, late embryos and hatchlings of squid are much smaller and are termed "paralarvae" because of their incomplete development when compared with adults [28]. As in cuttlefish eggs, some structural changes occur during the embryonic development. In cuttlefish eggs,
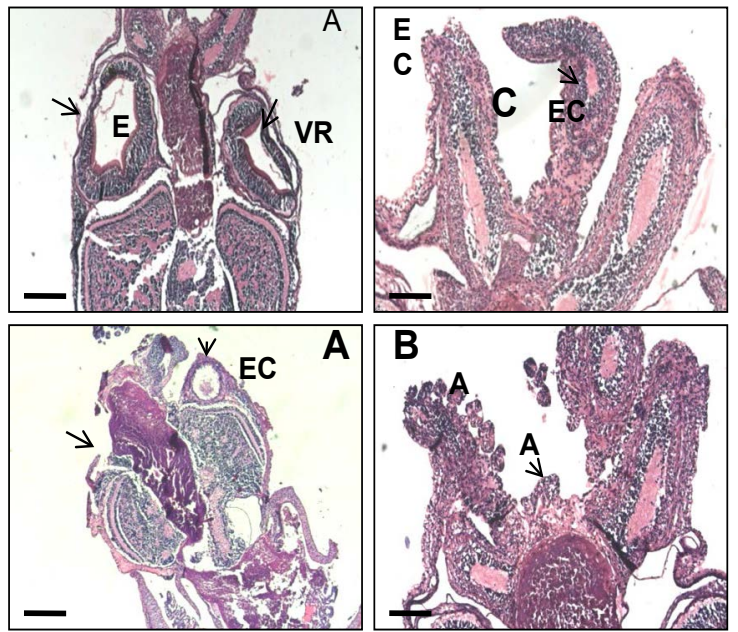

Figure 4A-D: Section through the paralarvae of Sepioteuthis lessoniana. 4A and 4B: Photomicrographs of control paralarvae showing normal aspect of eye cup $(E C)$, lengthy arms (A). scale bar: $50 \mu \mathrm{m} .4 \mathrm{C}$ and 4D: Photomicrographs of cadmium treated paralarvae showing partial eye cup on the right side (EC) and stunted growth of arm tips (A). scale bar: $50 \mu \mathrm{m}$.
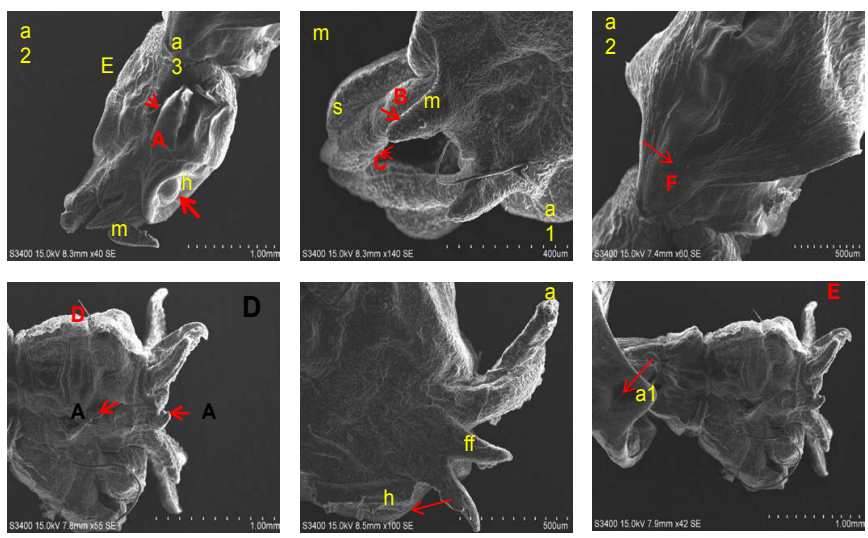

Figure 5A-F: Scanning electron micrographs of the paralarvae of Sepioteuthis lessoniana. $5 A-5 C$ is the section of control paralarvae. (A) Showing normal morphological aspect of head $(h)$, well developed eye invagination $(E)$, funnel fold (ff), mantle (m) and arm (a). (B), magnified view of arm 1(a1), arm 2(a2) and arm 3(a3) with suckers (S), (C). magnified view of mantle (m). 5D-5F: Section of Cd treated paralarvae. (D). Showing Distorted appearance of the head with rudiment of head (h), funnel fold (ff), stunted arms (a). (E). Magnified view of arm 1 (a1) and arm 2(a2) arrow: note the stunted growth of arms. $(F)$. Note the weekly joint mantle from the head $(m)$.

it has been demonstrated that the increased permeability of the egg to some metals is correlated with this swelling process $[29,30]$. As indicated by Bustamante et al. [7], irrespective of their morphological and evolutionary variety and heterogeneity in their geographical distribution, cephalopods have in common the capability to concentrate $\mathrm{Cd}$ at extremely high levels. Therefore, $\mathrm{Cd}$ concentrations could be risky for the squid populations in natural conditions. Spawning behaviour observed in this study was similar to those shown in previous studies [31]. Temperature is the main abiotic factor influencing growth during the embryonic and hatchling stages of cephalopods [32,33]. This is a relatively normal result due to the use of ambient temperature for incubation in the current study. However, at constant incubation temperatures, body size becomes larger in hatchlings that hatch later in some cephalopod species [34] but it does not vary in other species [35]. As in other coleoid cephalopods, S. atlantica showed an inverse relationship between temperature and developmental duration [36]. Our comparison between the tested temperatures did not show apparent differences in. Sen and Sunlu [1] explained that cadmium adversely affected development, survival and hatching of $L$. vulgaris eggs. In the present study the nominal concentration of of $25 \mu \mathrm{g} \mathrm{Cd} / \mathrm{L}$ was used to augment the deformities associated with cadmium in the embryonic and post embryonic behavior of squid.

Treatments without $\mathrm{Cd}$ showed no chorion expansion and resulted in $99.2 \pm 1.6 \%$ success in hatchability. In comparison with treatments receiving $\mathrm{Cd}$ recorded organogenesis and just before hatching showed malformations and decreased hatching percentage. As reported by Sen [21], total hatching and hatching success rates were calculated as 98.8-98.9\% and $84-86 \%$, respectively, and the hatching period of the paralarvae occurred between the days $5-7$ at $18 \pm 1^{\circ} \mathrm{C}$. The morphology of paralarvae has also been described during observation of embryonic development. Watanabe et al. [37] showed that hatchlings have only one or two suckers near the base of arms I and II, and that in 4-5-dayold paralarvae the distal portion of tentacles terminates in acute tips. In this study, paralarvae treated with $\mathrm{Cd}$ had stunted growth of arms and tentacles with acute tips. Also, they calculated total hatching and hatching successes as $98.2 \pm 1.6 \%$ and $94 \pm 2.3 \%$, respectively, and the hatching period of the paralarvae lasted 4 days at $19.8 \pm 1.6^{\circ} \mathrm{C}[22]$. 
Citation: Vasanthi LA, Revathi P, Munuswamy N, Babu RR (2016) Effect of Cadmium on the Embryonic Development and Hatching Rhythm of Big Fin Squid Sepioteuthis lessoniana, Lesson (1830) from Palk Strait, East Coast of India. J Biodivers Endanger Species 4: 159. doi:10.4172/23322543.1000159

Page 5 of 6

When compared to those data with the current results, it is prominent that the total hatching was nearly the same proportion in the control group, while, hatching successes was significantly lower in Cd treated groups. The embryo mortality rates of $100 \%$ occurred within 1 day of cadmium treatment. However in control, the embryos were survived more than 3 days. So far, numberless studies were carried out about adverse effects of cadmium on accumulation, behaviour, biochemistry, cell(s), development, enzyme(s), growth, histology, mortality, physiology and reproduction in molluscs [38].

Post-hatch conditions were similar for all hatchlings, despite being raised at different developmental temperatures. This may have changed the physiological consumption of the yolk [39]. Yolk consumption was studied in crabs (Chasmagnathus granulate), with salinity as the variable factor, and although salinity stress resulting in an increase in egg size [40]. At the time of hatching, the young squids possess a large internal yolk supply and appear, on morphological grounds (no apparent mouth, suckers without acetabulae, and so forth), to be incapable of feeding. The treated group shows the presence of vitellin reserves on the head. In control, all of the hatchling types had distinctive chromatophore patterns. Newly hatched individuals showed expanded chromatophores of dark brown colour on a yellowish background along the whole body, and they often assumed a "flamboyant" arm display [41]. The chromatophore arrangements in the paralarvae of $S$. lessoniana are similar to those reported for L. opalescens [42], L. vulgaris $[25,43]$ and $L$. reynaudii $[44,45]$. The present observations on cadmium treated paralrvae showed the absence of chromatophores on the body. Variability in hatchlings from the same egg capsule can be associated with intrinsic factors like multiple paternities [46], or with extrinsic factors such as the possible differences in the oxygen availability to embryos. Afterwards, they moved quickly towards the prey in order to attain appropriate attacking distance [47].

Histological analyses demonstrated that the eye stalks are very conspicuous projections from the sides of the dorsal end of the embryo. The ridges of the head divided into three arms, upon each side of the body, about half-way between the mantle and the opposite pole of the egg. Eye primordial was not clear as in control. The pair of arms makes their appearance as buds upon the next pair and appeared as elevations of the integument upon the surface of the body. Rodrigues et al. [48] had described the histological aspect of the paralarvae of Atlantic bobtail squid Sepiola atlantica.

The developmental stages of arm suckers can vary with arm position in ommastrephid and onychoteuthid paralarvae, in $T$. rhombus paralarvae arm sucker development clearly occurs in two separate stages [49]. The proximal suckers of T. rhombus develop with chitinous rings, whereas the middle suckers are bud-like in shape and have no chitinous rings. In this study, the presence of arms and suckers were absolutely normal in control groups compared to $\mathrm{Cd}$ treated group. Wakabayashi, et al. [50], studied the detailed morphological aspects of the paralarvae and its arm and tentacle arrangements in the diamondback squid Thysanoteuthis rhombus Troschel (1857). Similarly, the present study also corroborates the finding of Wakabayashi, et al. [50] in control group. Other than perhaps, cadmium treated group exhibited the stunted growth of arms and tentacles as described in scanning electron microscopoy. Hence it was confirmed that, cadmium adversely affected development, survival and hatching of S. lessoniana eggs and paralarvae.

\section{Conclusion}

In conclusion, the present concentration exhibited toxic effects to both eggs and the paralarvae. Therefore, the Cd level as high as we used in the current study could give good information on dangerous $\mathrm{Cd}$ levels on S. lessoniana. Consequently, hatching is an extremely sensitive period in early cephalopod ontogenesis. Taking that into consideration in S. lessoniana, Cd adversely affected not only one mechanism of development, but also whole developmental and hatching process. Finally, we recommended that more detailed studies should be examined investigating the metal kinetics of penetration and the properties of the S. lessoniana egg capsule towards the metals etc. Moreover, the current results indicate future areas of research in squids, which may be fruitful towards understanding the effect of Cd on the innate behavioral response and metabolism.

\section{Acknowledgement}

Financial assistance to Ms. L. Arockia Vasanthi (PDF), from Dr. D.S. Kothari Post-Doctoral Fellowship Scheme (UGC) Government of India, New Delhi is gratefully acknowledged.

\section{References}

1. Sen $\mathrm{H}$, Sunlu $\mathrm{U}$ (2007) Effects of Cadmium $\left(\mathrm{CdCl}_{2}\right)$ on development and hatching of eggs in European squid (Loligo vulgaris Lamarck, 1798) (Cephalopoda: Loliginidae). Environ Monit Assess 133: 371-378.

2. Wicklund GA, Haux C, Hogstrand C (1992) Chronic toxicity and metabolism of $\mathrm{Cd}$ and $\mathrm{Zn}$ in juvenile minnows (Phoxinus ohoxinus) exposed to a $\mathrm{Cd}$ and $\mathrm{Zn}$ mixture. Canadian J Aquat Fish Sci 49: 2070-2079.

3. Wilson RW, Taylor EW (1993) The physiological responses of freshwater rainbow trout, Oncorhynchus mykiss, during acutely lethal copper exposure. J Comp Physiol 163B: 38-47.

4. Stasiunaitel $P$ (1999) Long-term heavy metal mixture toxicity to embryos and alevins of rainbow trout (Oncorhyncus mykiss). Act Zool Litu Hydrobiol 9: 4046.

5. Martin JH, Flegal AR (1975) High copper concentrations in squid livers in association with elevated levels of silver, cadmium, and zinc. Mar Biol 30: 5155.

6. Bustamante P, Caurant F, Fowler SW, Miramand P (1998a) Cephalopods as a vector for the transfer of cadmium to top marine predators in the North East Atlantic Ocean. Sci Total Environ 220: 71-80.

7. Bustamante P, Teyssié JL, Fowler SW, Cotret O, Danis B, et al. (2002a) Biokinetics of zinc and cadmium accumulation and depuration at differen stages in the life cycle of the cuttlefish Sepia officinalis. Mar Ecol Prog Ser 231: $167-177$

8. Bustamante P, Teyssié JL, Danis B, Fowler SW, Miramand P, et al. (2004) Uptake, transfer and distribution of silver and cobalt in tissues of the common cuttlefish Sepia officinalis at different stages of its life cycle. Mar Ecol Prog Ser 269: 185-195.

9. Sorensen EM (1991) Cd. In: Sorensen EM (Ed.), Metal poisoning in fish. Boca Raton, FL: CRC. pp. 175-234.

10. Vogiatzis AK, Loubourdis NS (1997) Uptake, tissue distri-bution and depuration of cadmium (Cd) in the frogs Rana ridibunda. Bull Environ Contam Toxicol 59: 770-777.

11. Revathi P, Arockia Vasanthi L, Munuswamy N (2011) Effect of cadmium on the ovarian development in the freshwater prawn Macrobrachium rosenbergii (De Man). Ecotoxicol Environ Safe 74: 623-629.

12. Pickering WF (1995) General strategies for speciation. In: Ure AM, Davidson CM (Eds.) Chemical speciation in the environment. London: Chapman and Hall. pp. 6-32.

13. Campbell PGC (1995) Interactions between trace metals and aquatic organisms: A critique of the free-ion activity model. In: Tessier A, Turner DR (Eds.), Metal speciation and bioavailability in aquatic systems. Chichester: Wiley. Publishers pp. 45-102.

14. Saager PM, De Baar HJW, De Jong JTM, Nolting RF, Schijf J (1997) Hydrograpy and local sources of dissolved trace metals $\mathrm{Mn}, \mathrm{Ni}, \mathrm{Cu}$ and $\mathrm{Cd}$ in the northeast Atlantic Ocean. Mar Chem 57: 195-216.

15. Craig S, Overnell J (2003) Metals in squid, Loligo forbesi, adults, eggs and 
Citation: Vasanthi LA, Revathi P, Munuswamy N, Babu RR (2016) Effect of Cadmium on the Embryonic Development and Hatching Rhythm of Big Fin Squid Sepioteuthis lessoniana, Lesson (1830) from Palk Strait, East Coast of India. J Biodivers Endanger Species 4: 159. doi:10.4172/23322543.1000159

hatchlings. No evidence for a role for Cu- or Znmetallothionein. Comp Biochem Physiol C 134: 311-317.

16. Bustamante $P$, Cherel $Y$, Caurant F, Miramand $P$ (1998b) Cadmium, copper and zinc in octopuses from Kerguelen Islands, Southern Indian Ocean. Polar Biol 19: 264-271.

17. Bustamante P, Cosson RP, Gallien I, Caurant F, Miramand P (2002b) Cadmium detoxification processes in the digestive gland of cephalopods in relation to accumulated cadmium concentrations. Mar Environ Res 53: 227-241.

18. Gerpe MS, de Moreno JEA, Moreno VJ, Patat ML (2000) Cadmium, zinc and copper accumulation in the squid Illex argentinus from the Southwest Atlantic Ocean. Mar Biol 136: 1039-1044.

19. Koyama J, Nanamori N, Segawa S (2000) Bioaccumulation of waterborne and dietary cadmium by oval squid Sepioteuthis lessoniana, and its distribution among organs. Mar Pollut Bull 40: 961-967.

20. Sen $\mathrm{H}$ (2004) A preliminary study on the effects of salinity on egg development of European squid (Loligo vulgaris Lamarck, 1798). Israeli J Aquacult. Bamidgeh 56: 95-101.

21. Sen H (2005a) Incubation of European Squid (Loligo vulgaris Lamarck, 1798) eggs at different salinities. Aquacult Res 36: 876-881.

22. Sen H (2005b) Temperature tolerance of loliginid squid (Loligo vulgaris Lamarck, 1798) eggs in controlled conditions. Turkish J Fish Aquat Sci 5: 5356.

23. Villanueva R, Arkhipkin A, Jereb $P$, Lefkaditou Lipinski MR, Peralas-Raya $C$ et al. (2003) Embryonic life of the Ioliginid squid Loligo vulgaris: comparison between statoliths of Atlantic and Mediterranean populations. Mar Eco Prog Ser 253: 197-208.

24. D'Aniello A, Pischetola M, Vanacore F, De Nicola M (1990) Effects of mercury, $\mathrm{Cd}$ and copper on the development and viability of Loligo vulgaris and Sepia officinalis embryos. The Italian Journal of Biochemistry 39: 130-133.

25. Naef A (1928) Die Cephalopoden. Fauna Flora Golfo Napoli, 35. monograph part I 2: 37.

26. Arnold JM (1965) Normal embryonic stages of the squid, Loligo pealii [sic] (Lesuer). Biol Bull 128: 24-32

27. Boletzky SV (1986) Encapsulation of cephalopod embryos: a search for functional correlations. Amer Malac Bull 4: 217-227.

28. Fioroni $P$ (1990) Our recent knowledge of the development of the cuttlefish (Sepia officinalis). Zool Anz 224: 1-25

29. Lacoue-Labarthe T, Oberhänsli FR, Teyssié JL, Warnau M, Koueta N, et al (2008) Differential bioaccumulation behaviour of $\mathrm{Ag}$ and $\mathrm{Cd}$ during the early development of the cuttlefish Sepia officinalis. Aquat Toxicol 86: 437-446.

30. Lacoue-Labarthe $T$, Warnau $M$, Oberhänsli $F$, Teyssié JL, Bustamante $P$ (2010) Contrasting accumulation biokinetics and distribution of $241 \mathrm{Am}, \mathrm{Co}$, $\mathrm{Cs}, \mathrm{Mn}$ and $\mathrm{Zn}$ during the whole development time of the eggs of the common cuttlefish, Sepia officinalis. J Exp Mar Biol Ecol 382: 131-138.

31. Rodrigues M, Garcı ME, Troncoso JS, Guerra A (2010) Burying behaviour of the, Atlantic bobtail squid Sepiola atlantica (Cephalopoda: Sepiolidae). Ital J Zoo 77: 247-251.

32. Boletzky SV (1987) Embryonic phase. In: Boyle PR (Ed.) Cephalopod life cycles. Academic Press, London. 2: 5-31.
33. Villanueva R, Moltschaniwskyj NA, Bozzano A (2007) Abiotic in Xuences on embryo growth: statoliths as experimental tools in the squid early life history. Rev Fish Biol Fish 17: 101-110.

34. Ikeda Y, Arai N, Sakamoto W, Yoshida K (1999) Trace elements in cephalopod calcified tissue: cuttlebone as a possible tracer for life historical events of cuttlefish. Int J PIXE 9: 335-343.

35. Briceño-Jacques F, Mascaró M, Rosas C (2010) GLMM-based modelling of growth in juvenile Octopus maya siblings: does growth depend on initial size? ICES Journal of Marine Science 67: 1509-1516.

36. Boletzky S (2003) Biology of early life stages in cephalopod molluscs. Adv Mar Biol 44: 143-203.

37. Watanabe KK, Ando K, Tsuchiya Segawa S (1998) Late embryos and paralarvae of diamondback squid Thysanotuethis rhombus Troschel, 1857 Venus 57: 291-301.

38. PAN. Pesticides Database-Chemicals: Cadmium-Identification, toxicity, use, water pollution potential, ecological toxicity and regulatory information.

39. Gimenez L, Torres G (2002) Larval growth in the estuarine crab Chasmagnathus granulate: the importance of salinity experienced during embryonic development, and the initial biomass. Mar Biol 141: 877-885.

40. Gimenez L, Anger K (2001) Relationships among salinity, egg size, embryonic development and larval biomass in the estuarine crab Chasmagnathus granulate, Dana 1851. J Exp Mar Biol Ecol 260: 241-257.

41. Mauris ME (1989) Colour patterns and body postures related to prey capture in Sepiola affinis (Mollusca: Cephalopoda). Mar Behav Physiol 14: 189-200.

42. McConathy DA, Hanlon RT, Hixon RF (1998) Chromatophore arrangements of hatchling loliginid squids (Cephalopoda, Myopsida). Malacologia. 19: 279-288.

43. Hanlon RT, Boletzky SV, Okutani T, Perez-Gandaras G, Sanchez P, et al (1992) In: Sweeney MJ, Roper CFE, Mangold KM, Clarke MR, Boletzky SV (eds.), 'Larval' and Juvenile Cephalopods: A Manual for Their Identification. Smithsonian Contributions to Zoology 513. Washington, DC p. 282.

44. Vecchione M, Lipinski MR (1995) Descriptions of the paralarvae of two loliginid squids in Southern African waters. S Afr J Mar Sci 15: 1-7.

45. Blackburn S, Sauer WHH, Lipinski MR (1998) The embryonic development of the Chokka Squid Loligo vulgaris reynaudii d'Orbigny, 1845. The Veliger 41 : 249-258.

46. Buresch KM, Hanlon RT, Maxwell MR, Ring S (2001) Microsatellite DNA markers indicate a high frequency of multiple paternity within individual fieldcollected egg capsules of the squid Loligo pealeii. Mar Ecol Prog Ser 210 161-165.

47. Messenger JB (1968) The visual attack of the cuttlefish Sepia officinalis. Anim Behav 16: 342-357.

48. Rodrigues M, Garcı ME, Troncoso JS, Guerra A (2011) The embryonic phase and its implication in the hatchling size and condition of Atlantic bobtail squid Sepiola atlantica 65: 211-216.

49. Wakabayashi T (2002) Studies of morphology, distribution and species assemblage of paralarvae from western Australian waters. Ph.D. Thesis, Tokyo University of Fisheries, Tokyo, Japan p. 580

50. Wakabayashi T, Tsuchiya K, Segawa S (2005) Morphological changes with growth in the paralarvae of the diamond back squid Thysanoteuthis rhombus Troschel, (1857). Phuket mar biol Cent Res Bull 66: 167-174. 